\title{
The effect of changes in manganese concentrations on cellulase yield from bagasse fermented with mutagenised strain of Aspergillus niger AH3
}

\author{
D. DAMISA ${ }^{1 *}$, J. B. AMEH ${ }^{2}$ and V. J. UMOH ${ }^{2}$ \\ ${ }^{1}$ Department of Applied Science, College of Science and Technology, Kaduna Polytechnic, \\ PMB 2021 Kaduna, Nigeria. \\ ${ }^{2}$ Department of Microbiology, Ahmadu Bello University, Zaria, Nigeria. \\ *Corresponding author, E-mail: damisaduro@yahoo.com
}

\begin{abstract}
The effect of changes in manganese ion concentrations on cellulase yield from bagasse fermented with a hydroxylamine derived mutant of Aspergillus niger were investigated in a batch culture shake flask fermentations. Three different concentrations were studied using the Mandel-Weber basal medium adjusted to $\mathrm{pH}$ 4.8. Enzyme production profile was monitored over a seven day period. Bagasse was found to be a good carbon source and it induced active cellulase production. Cellulase activities were recorded as 0.07256 $\mathrm{IU} / \mathrm{ml} / \mathrm{min}, 0.04820 \mathrm{IU} / \mathrm{ml} / \mathrm{min}$ and $0.04258 \mathrm{IU} / \mathrm{ml} / \mathrm{min}$ for $0.16 \mathrm{~g} / \mathrm{L}, 0.59 \mathrm{~g} / \mathrm{L}$ and $0.67 \mathrm{~g} / \mathrm{L}$ of manganese respectively. Day 4 appears to be best for optimum production of the enzyme at the concentrations studied. Increasing concentrations of manganese ion which is a requirement for pectolytic enzyme and citric acid accumulation in Aspergillus niger does not promote excellent cellulase production from bagasse.

(C) 2008 International Formulae Group. All rights reserved.
\end{abstract}

Keywords: cellulase, manganese, bagasse, pectolyic, hydroxylamine, mutant, Aspergillus niger

\section{INTRODUCTION}

Effective utilization of cellulosic biomass as renewable carbon sources is dependent on the development of economically practicable process technologies for the production of cellulase enzyme needed for the hydrolysis of the biomass to low molecular weight sugars of the hexoses and pentoses group. Large quantities of agricultural residues such as bagasse that litter our streets accumulate and result not only in the deterioration of the environment, but also in the loss of potentially valuable materials which can be processed to yield a number of value added products such as food, fuel, feed and a variety of chemicals. The conversion of cellulosic biomass to fermentable sugars through biocatalyst cellulase obtained from cellulolytic microorganisms will certainly offer potential to reduce environmental pollution (Lynd et al., 2002). High cost of production of cellulases has impeded successful cellulose bioconversion for industrial usage (Chahal et al., 1996). One of the different approaches to overcome this limitation is to research and explore for organisms with secretion of cellulase enzymes in ample quantities and to optimize enzyme production with them. Several fungi and bacteria are capable of producing the cellulase into culture broth (Cai, 2000). Many moulds are exploited for the large amounts of specific proteins they produce though the level of production of such proteins in native strains is usually far too low for commercial exploitation. Remarkable improvements in secondary metabolites and protein expression have been obtained with traditional strain improvement approach based on mutagenic scheme or media formulation approach (Punt et al., 2002). Aspergillus cultures are quite amenable and adaptive and thus capable of 
utilizing a wide range of substrates for energy generation and synthesis. Aspergillus niger is a common member of the microbial communities found in soils, and plays a significant role in the global carbon cycle. This saprobe produces a wide array of hydrolytic and oxidative enzymes involved in the breakdown of plant lignocellulose. In industrial processes, Aspergillus niger has been used for the production of citric acid and recently they have been exploited for the production of numerous enzymes because they have the capacity to secrete large amounts of protein into their growth medium (Gouka et al., 1997). To achieve the accumulation of certain metabolite the maintenance of strictly defined cultivating conditions is necessary. With pectolytic enzyme accumulation, the maintenance of proper metal ion concentration is one of the main requirements for commercial profitability of the technical process (Ali et al., 2001). It is known that in Aspergillus niger trace metal ions, especially manganese and copper essentially influence citric acid accumulation (Berry et al., 1977). Manganese is a micronutrient required as a cofactor in many enzyme systems, for example in the TCA cycle and in nucleic acid synthesis (Griffin, 1994). The physiological effects that manganese exerts on fungi vary considerably (Auling, 1994) for example, in A. niger, manganese deficiency results in the reduction of the levels of lipid, protein, and nucleic acids (Kubicek et al., 1979). Hatakka (1994) observed that the chemical nature and abundance of manganese constitute the basis for its involvement in lignin biodegradation. Studies carried out by Forrester et al. (1988) have shown that $\mathrm{Mn}(\mathrm{III})$ is an important lignolytic agent, but requires a suitable chelator. Manganese activates other enzymes, such as superoxide dismutase, protein kinase, adenyl cyclase, and RNA polymerase (Garraway and Evans 1984). Zonneveld (1975) found that manganese controls sexual differentiation in Aspergillus nidulans and observed that manganese deficient cells of $A$. nidulans failed to form cleistothecia.

Apart from Nitrogen and Carbon sources, several other essential elements like sulphur, calcium, magnesium, potassium, phosphorus and numerous trace elements such as iron, copper, cobalt, zinc, manganese may be required in the medium to support active cellular function. Trace elements often serve as cofactors in enzymatic reactions (Mulimani and Ramlingam, 1995; Duffaud et al., 1997). However, there is paucity of information regarding the effect of manganese concentration on cellulase yield by Aspergillus niger. Therefore, this work was undertaken to investigate the effect of changes in manganese concentrations on cellulase yield from bagasse fermented with mutagenised strain of Aspergillus niger AH3.

\section{MATERIALS AND METHODS \\ Preparation of Bagasse}

Sugarcane bagasse was collected from streets in Samaru, Zaria. The samples were chopped into bits and pounded into coarse particle sizes, then washed exhaustively with hot water several times (Rezende et al., 2002) to remove residual sugar that may be adhering to the biomass. They were further sun dried for three weeks to eliminate moisture. Sun dried samples were further oven dried at $50{ }^{\circ} \mathrm{C}$ to a constant weight to make them susceptible to ball milling. Milled samples were sieved to particle size of $850 \mu$ which, was used for all experimentation.

\section{Microorganism}

Aspergillus niger strain AH3 was selected as a hyper-cellulase producing strain after chemical mutagenesis using hydroxylamine and screening using Congo Red assay Medium (Teather and Wood, 1982).The strain was stored on PDA slants and kept under refrigeration in the Department of Microbiology, Ahmadu Bello University, Zaria.

\section{Cultivation}

The medium favouring cellulase enzyme synthesis according to Mandels et al. (1981) was prepared as follows (g/L): Pulverized bagasse, 10; yeast extract, 0.2; Peptone, 1; $\left(\mathrm{NH}_{4}\right)_{2} \mathrm{SO}_{4}, 4 ; \mathrm{KH}_{2} \mathrm{PO}_{4}, 2$; Urea, $0.3 ; \mathrm{MgSO}_{4} .7 \mathrm{H}_{2} \mathrm{O}, 0.3, \mathrm{CaCl}_{2}, 0.3 ; \mathrm{FeSO}_{4}$. $7 \mathrm{H}_{2} \mathrm{O}, 0.5 ; \mathrm{ZnSO}_{4}, 0.14 ; \mathrm{CoCl}_{2}, 2$; Tween-80, $0.1 \%$ and $\mathrm{pH}$ adjusted to 6 using $0.05 \mathrm{M}$ sodium hydroxide solution. The medium was divided into three batches of $100 \mathrm{ml}$ each into $250 \mathrm{ml}$ capacity Erlenmeyer flasks and $\mathrm{MnSO}_{4} .4 \mathrm{H}_{2} \mathrm{O}$, which serves as the source of manganese ion in the broth added at concentrations of $0.16,0.59$ and $0.67 \mathrm{~g} / \mathrm{L}$ 
respectively. The media were sterilized at 121 ${ }^{\circ} \mathrm{C}$ for 15 minutes, cooled to room temperature and inoculum ratio of $10 \%$ corresponding to $1.0 \times 10^{6}$ cells per $\mathrm{ml}$ obtained seeded aseptically into the flasks. Experiments were carried out in $250 \mathrm{ml}$ baffled Erlenmeyer flasks with $100 \mathrm{ml}$ of sterilized medium on a rotary shaker (200 rpm) at ambient temperature. Aliquots of the fermented broth were removed from each flask and the contents analysed every 24 hours.

\section{Analytical Methods}

The total cellulase activity, termed saccharifying cellulase, was determined using the Filter Paper Unit (FPU) assay proposed by Ghose (1987). One unit of cellulase corresponds to the amount necessary to form one milligram $(\mathrm{mg})$ of glucose per minute at $50{ }^{\circ} \mathrm{C}$. Reducing sugar estimation was done by dinitrosalicylic acid method (DNS) (Miller, 1959). All experimentations and assays were replicated.

\section{RESULTS}

The effect of cultivation regime on cellulase production by Aspergillus niger in bagasse amended with different concentrations of manganese using Mandels et al. (1981) medium as basal medium is presented in Figure 1. The activity of cellulase is higher when lower concentrations $(0.16 \mathrm{~g} / \mathrm{L})$ of manganese was used. Increasing concentration of the salt gave a corresponding decrease in enzyme expression which is a sharp contrast to citric acid production by Aspergillus niger. Optimum cellulase expression was obtained at 96 hours in all instances. Highest was $0.07256 \mathrm{IU} / \mathrm{ml} / \mathrm{min}$, followed by $0.04820 \mathrm{IU} / \mathrm{ml} / \mathrm{min}$ then 0.04258 $\mathrm{IU} / \mathrm{ml} / \mathrm{min}$ for $0.16 \mathrm{~g} / \mathrm{L}, 0.59 \mathrm{~g} / \mathrm{L}$ and $0.67 \mathrm{~g} / \mathrm{L}$ manganese concentrations in the fermentation broths respectively. The cellulase standard gave an activity of $0.08968 \mathrm{IU} / \mathrm{ml} / \mathrm{min}$. Increased manganese amendments were not found to be advantageous to cellulase production by the mould.

\section{DISCUSSION}

Traditionally cellulosic waste disposals in our setting have been incineration and incorporation into the soil but incineration option promotes particulate matter discharge into the atmosphere, thereby increasing concentrations of carbon dioxide and other green house gases in the earth's atmosphere. A way of addressing this sensitive issue could be through the development of biowaste and scientific innovation as a means of converting these wastes into feed stocks which this work has addressed

Due to the vast role this enzyme plays in certain industrial processes, its manufacture from lignocellulosic wastes has proven to be of great importance to the enzyme industry. The presence of manganese has been reported to significantly affect lignin degradation in many white rot fungi (Kerem and Hadar, 1995). High manganese concentration may have an extra-cellular oxidizing activity. The effect of Mn on cellulose biodegradation may lead to a better definition of the unique role of $\mathrm{Mn}$ in lignin degradation by Pleurotus ostreatus. Cellulose degradation in nature has been suggested to require the activity of small agents that can attack the cellulose at the beginning of lignocellulose decay, thereby enabling the relatively large cellulases to penetrate the plant tissue (Gunasekaran, 1980). The effect of Mn levels in the medium on the growth, ligninolytic enzymes profile and lignocellulose degradation by Pleurotus ostreatus according to Kerem, and Hadar (1995) has enabled the study of a Mn deficient medium as well as high concentrations of manganese, added as $\mathrm{MnSO}_{4}$, up to $4.5 \mathrm{mM}$ in the growth medium to the performance of the organism. $\mathrm{MnO}_{2}$ was found to precipitate rapidly in most of the manganese-containing media indicating an extracellular oxidizing activity specific to manganese. The precipitation of manganese from the growth medium of $P$. ostreatus probably occurred via its oxidation to higher oxidative forms. This work is therefore in agreement with previous report Phanerochaete. chysosporium (Perez and Jeffries, 1992), suggesting that the oxidation of Manganese to $\mathrm{MnO}_{2}$ by Aspergillus niger AH3 may have been the reason for the lower activities of the enzyme at higher concentrations of the $\mathrm{MnSO}_{4} .4 \mathrm{H}_{2} \mathrm{O}$.

From technical point of view, enhancing the cellulase enzyme production via media formulation approach will permit the ultimate objective of consolidating on the pre-treatment and saccharification procedure often employed on crystalline substrates. 


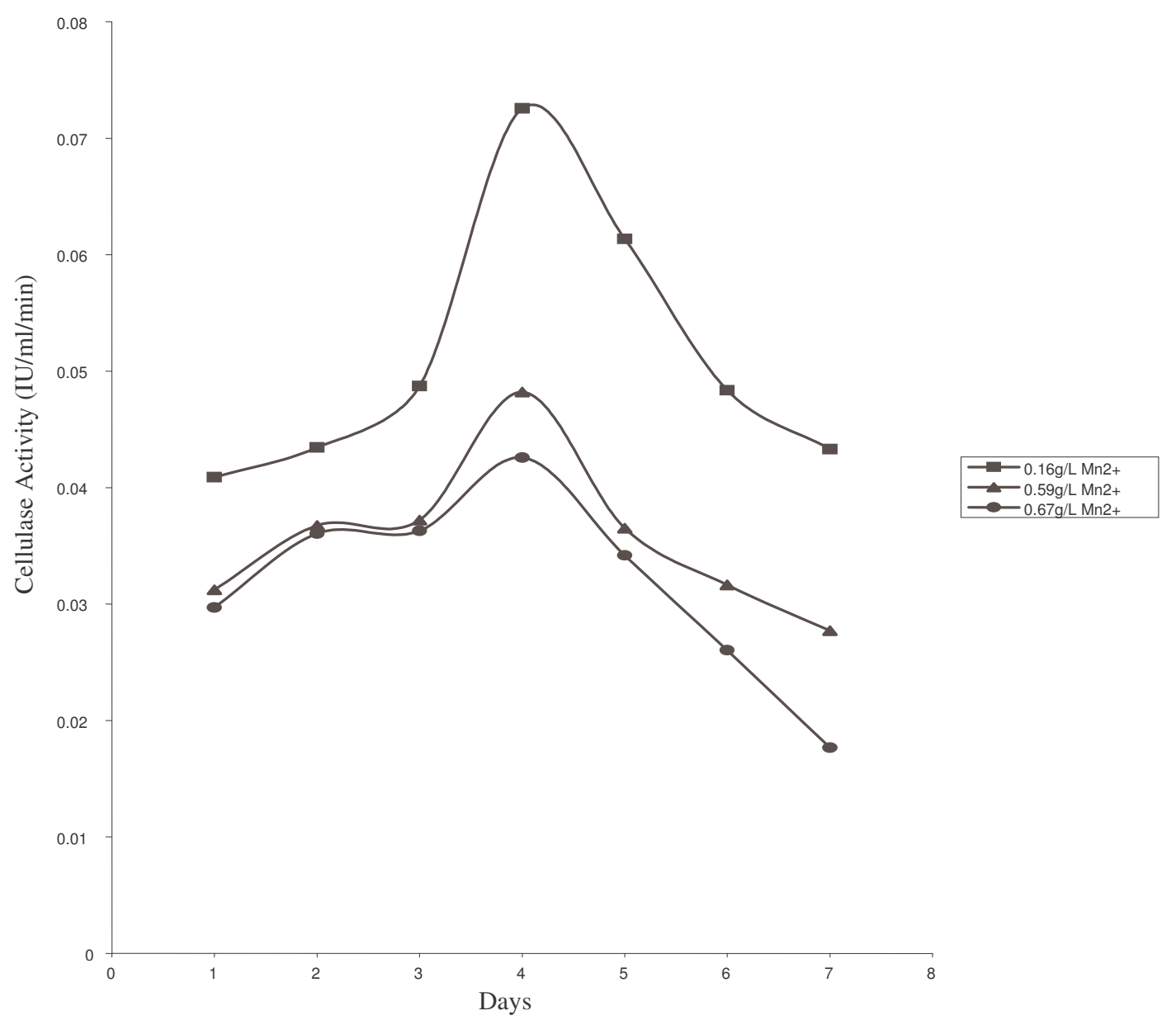

Figure 1: Effect of changes in manganese ion concentrations on cellulase expression by Aspergillus niger $\mathrm{AH} 3$.

Increasing concentrations of manganese ion which is a requirement for pectolytic enzyme and citric acid accumulation in Aspergillus niger does not promote excellent cellulase production from bagasse. The findings enabled the study of a manganese normal medium as recommended by Mandels et al. (1981) as well as high concentrations of $\mathrm{Mn}^{2+}$ added as manganese sulphate $\left(\mathrm{MnSO}_{4} \cdot 4 \mathrm{H}_{2} \mathrm{O}\right)$ to the growth medium.

\section{REFERENCES}

Ali S, Haq I, Qadeer MA. 2001. Effect of mineral nutrient on the production of citric acid by Aspergillus niger. Online Journal of Biological Sciences, 32: 31-35.
Auling G. 1994. Manganese: function and transport in fungi. In Metal Ions in Fungi, Winkelmann G, Winge DR (eds). Dekker: New York; 215-236.

Berry DR, Chmiel A, Al Obaidy Z. 1977. Citric acid accumulation by Aspergillus niger. In Genetics and Physiology of Aspergillus, Smith JE, Pateman JA (eds). Academic Press: London; 405-423.

Cai J. 2000. Analysis of cellulolytic activities of chimeric proteins from Clostridium cellulovorans. M.Sc Thesis, Department of Biotechnology, University of New South West, pp. 1-64.

Chahal PS, Chahal DS, Le GBB. 1996. Production of cellulases in solid state fermentation with Trichoderma reesei 
MCG 80 on wheat straw. Applied Biochemistry and Biotechnology, 57/58: 433-442.

Duffaud GD, McCutchen CM, Leduc P, Parker KN, Kelly RM. 1997. Purification and characterization of extremely thermostable beta-mannanase, $\beta$ mannosidase, and $\alpha$-galactosidase from the hyperthermophilic eubacterium Thermotoga neapolitana 5068. Applied and Environmental Microbiology, 63: 169-177.

Forrester IT, Grabski AC, Buegess RR, Leatham GF. 1988. Manganese dependent peroxidase and the degradation of lignin. Biochemical and Biophysical Research Communication, 157: 992-999.

Garraway MO, Evans RC. 1984. Fungal Nutrition and Physiology. Miley: New york.

Ghose TK. 1987. Measurement of cellulase activities. Pure and Applied Chemistry, 59: 257-268.

Gouka RJ, Punt PJ, van denHondel C. 1997. Efficient production of secreted proteins by Aspergillus. Progress, Limitations and Prospects. Applied Microbiology and Biotechnology, 47: 1-11.

Griffin DH. 1994. Fungal Physiology. WileyLiss: New York.

Gunasekaran M. 1980. Physiological studies on Phymatotrichum omnivorum XI cellulolytic enzymes. Mycologia, 72: 759766.

Hatakka AI. 1994. Lignin modifying enzymes from selected white rot fungi: production and role in lignin degradation. FEMS Microbiology Review, 13: 125-135.

Kerem Z, Hadar Y. 1995. Effect of manganese on preferential degradation of lignin by Pleurotus ostreatus during solid-state fermentation. Applied and Environmental Microbiology, 61: $3057-$ 3062.

Kubicek CP, Hampel W, Rohr M. 1979. Manganese deficiency leads to elevated amino acid pools in citric acid accumulating A. niger. Archives of Microbiology, 123: 73-79.

Lynd RL, Weiner PJ, Vanzyl WH, Pretorius TS. 2002. Microbial cellulose utilization:
Fundamentals and Biotechnology. Microbiology and Molecular Biology Reviews, 66: 506-577.

Mandels M, Medeiros JE, Andreotti RE, Bissett FH. 1981. Enzymatic hydrolysis of cellulose: evaluation of cellulase culture filtrates under use condition. Biotechnology and Bioengineering, 23: 2009-2026.

Miller GL. 1959. Use of Dinitrosalicylic acid reagent for determination of reducing sugar. Analytical Chemistry, 31: 426-428.

Mulimani VH, Ramlingam GN. 1995. Enzymic hydrolysis of Raffinose and Stachyose in soymilk by $\alpha$-galactosidase from Gibberella fujikuroi. Biochemistry and Molecular Biology International, 36: 897-905.

Perez J, Jeffries TW. 1992. Roles of manganese and organic acid chelators in regulating lignin degradation and biosynthesis of peroxidases by Phanerochaete chrysosporium. Applied Environmental Microbiology, 58: 24022409.

Punt PJ, van Biezen N, Conesa A, Albers A, Mangnus J, van den Hondel C. 2002. Filamentous fungi as cell factories for heterologous protein production (A review). Trends in Biotechnology, 20: 5865.

Rezende MI, Barbosa A, De M, Vasconelos AFD, Endo AS. 2002. Xylanase production by Trichoderma harzianum Rifai by solid state fermentation on sugarcane bagasse. Brazilian Journal of Microbiology, 33:459-466.

Teather RM, Wood PJ. 1982. Use of congo red polysaccharide interaction in enumeration and characterization of cellulolytic bacteria from bovine rumen. Applied and Environmental Microbiology 43: 777-780.

Zonneveld BJ. 1975. Sexual differentiation in Aspergillus nidulans. The requirement for manganese and the correlation between phosphoglucomutase and the synthesis of reserve material. Archives in Microbiology: 105-108. 